\title{
Ciacco, Brunetto, and the Voice of God
}

\section{Citation}

Pertile, Lino. 2013. "Ciacco, Brunetto, and the voice of god." In 'Legato con amore in un volume': Essays in Honour of John A. Scott, ed. John J. Kinder and Diana Glenn, 157-74. Florence, Italy: Olschki.

\section{Published Version}

https://www.olschki.it/libro/9788822261915

\section{Permanent link}

http://nrs.harvard.edu/urn-3:HUL.InstRepos:33954763

\section{Terms of Use}

This article was downloaded from Harvard University's DASH repository, and is made available under the terms and conditions applicable to Open Access Policy Articles, as set forth at http:// nrs.harvard.edu/urn-3:HUL.InstRepos:dash.current.terms-of-use\#OAP

\section{Share Your Story}

The Harvard community has made this article openly available.

Please share how this access benefits you. Submit a story.

Accessibility 


\section{LINO PERTILE}

\section{Ciacco, Brunetto and the Voice of God}

1. There has always been something legendary about John Scott. When I met him, in the autumn of 1968, I had just been recruited to teach for one year at the University of Reading as an "Assistant" in the Department of Italian Studies, while John, a Senior Lecturer, had just returned from a year's teaching in Earthly Paradise, aka California, and, during Gigi Meneghello's sabbatical, he was serving as our Head of Department. With his French background, impeccable trilingualism and cultivated taste, John was not only our major Dante and Renaissance scholar, but also our arbiter elegantiae, the undisputed connoisseur of good cars, wines and French cuisine. This is why my admiration for him grew even greater when he introduced me with total equanimity to the Senior Common Room, where the Reading professors took their daily meals and at the same time atoned for their sins.

Indeed, our daily walk to Park House for lunch felt very much like an act of self-denial, a purgatorial promenade. We knew what to expect. On the better days, Fish and Chips, but usually Toad in the Hole or Shepherd's Pie, or Steak and Kidney Pie, all swimming in gravy, served with potatoes (usually mashed, occasionally fried and soggy) and green boiled-to-death vegetables (peas, green beans, or brussels sprouts); for dessert, Rice pudding, Cabinet or Bread and Butter Pudding, and on special occasions Apple Pie or Rhubarb Crumble with Custard. A naturally moderate but discriminating consumer of food and drink, John detested custard. It offended his eye as much as his palate. After a long dispute with the staff, he was granted the option of replacing the custard with vanilla ice cream, a privilege that could occasionally be extended to those who accompanied him. We punished our senses as we fed our bodies while keeping our spirits occupied with talk of the Rock of Peter, Dante's Admiral, Farinata's magnanimity, and of course Ulysses' mad flight.

In those days, 'continental' food was hard to come by in Britain. One extra incentive about going to work in the British Library in London, was that, in the evening, one could walk to Camisa Deli in Soho, and then catch the train back to Reading gingerly carrying a briefcase heavy with San Daniele ham, vialone rice, dried porcini, and a bottle of Chianti. 
By the time I left Edinburgh in 1995, these items could be bought in any supermarket or corner shop in the British Isles. I haven't been back to the Reading University Senior Common Room for at least thirty years, but I'm confident that there too the gastronomic revolution has made deep inroads on the menu. In a few years, haute cuisine, once the preserve of the social elite, has become a popular sport, and gluttony fashionable even in Protestant Britain. On both sides of the Atlantic, most delicatessen shops have closed down, for exotic food and excellent wine are available everywhere and every day of the week, Sunday included. New cookbooks appear almost daily. Newspapers and magazines have regular sections or entire supplements devoted to food and wine, and there are countless TV shows which teach not just how to cook, but how to cook attractive and tasty dishes, and what wine to serve with each of them. If you don't like cooking, you can always go out, and eat Italian or French. And when you've had enough of Italian and French, you can switch to Indian and Chinese, or experiment with Japanese, Lebanese, Arab, Eritrean, Korean, Afghan, Mexican, and so on and so forth. Of course, there are plenty of newspaper articles and books that will tell you exactly where and what to eat anywhere in the world.

What has happened, at least in the prosperous West, is that people no longer think of food and drink as necessities, but in terms of the pleasure they bring to everyday life. If one overeats, it doesn't matter so long as one works out. Obesity is a major aesthetic issue with serious ramifications in personal and public health; however, it is not an issue of individual morality. If you are a Catholic, when was the last time you confessed to have added double cream to your spaghetti sauce, and drunk more cabernet than you needed to quench your thirst? Gluttony is no longer felt to be a sin, let alone a mortal one. We may still shed a tear for Dante's Lustful, but who weeps for the Gluttons? Yet Dante does place Gluttony in the third circle of hell, further down than Lust itself. Which means that, for the sommo poeta, you could be damned for fornicating with your sister or brother-in-law, but even more for enjoying a dish of roasted eels marinated in Vernaccia (Purg. 24. 24).

Gluttony was indeed considered a serious moral matter throughout the Middle Ages. Saint Thomas Aquinas writes that gluttony «consists properly of an immoderate pleasure in eating and drinking»; it «denotes, not any desire, but an inordinate desire», that is, a desire that goes beyond «the order of reason, wherein the good of moral virtue consists». ${ }^{1}$ This is a definition

\footnotetext{
${ }^{1}$ SAINT Thomas AquinAs, Summa theologiae, 2a.2ae.148,1.
} 
with which we can assume that Dante would have been familiar and in broad agreement, but it is hardly adequate to reveal the importance of, and the attention paid to, this sin in the Middle Ages. ${ }^{2}$ There exists a vast body of literature in Latin, from John Cassian to Alain de Lille, deprecating gluttony, and I will later mention a few authors and recurring themes. First, however , I must show how surprisingly little, despite the existence of this rich and varied background, Dante makes of gluttony. In fact, one of the many puzzling things about Inferno 6 is that, roughly speaking, less than the first quarter of the canto is about gluttony (ll. 1-33), while half of it is about Florentine politics (34-94), and the last quarter is about theological matters (95-115).

2. The first 33 lines of canto 6 are by far the most exciting. In the first two terzine, Dante transitions from the second to the third circle, that is, from Lust to Gluttony; he looks back to the grief he felt for the condition of the two lovers, Francesca and Paolo, and announces the presence around him of «new torments and new tormented souls». ${ }^{3}$ The transition is signalled by the sudden change from the past of «si chiuse» and «mi confuse» to the present of «mi veggio intorno», immediately followed by the crowding of three anxiety-inducing present subjunctives («io mi mova», «io mi volga», «io guati»).

The new circle is described in what I would call the present of eternity. The narrative focuses on the rain that falls upon the damned, a "piova» qualified with four adjectives packed in just one line brimming with energy: «etterna, maladetta, fredda e greve», a rain eternal, accursed, cold and heavy; a relentless rain that never changes its kind or its measure. It's not mere water either, for thick, heavy hailstones, filthy slosh and snow pelt down through the gloomy air, making the ground that receives this foul mixture stink: "pute la terra che questo riceve». ${ }^{4}$

Next, Dante introduces Cerberus, a violent and monstrous beast with three gullets barking incessantly over the spirits who are immersed in the filthy muck. In classical mythology, Cerberus is a three-headed dog, «stationed at the entrance to Hell to prevent the living from entering the infernal regions and the dead from escaping». ${ }^{5}$ Though in the Aeneid (6.417-

\footnotetext{
${ }^{2}$ See C. CASAgRANDE \& S. VeCChIO, I sette vizi capitali. Storia dei peccati nel Medioevo, Torino, Einaudi 2000, pp. 124-148.

${ }^{3}$ Throughout this article, unless otherwise stated, I'm quoting from John Sinclair's translation of The Divine Comedy, New York, Oxford University Press 1961-1964.

${ }_{4}^{4}$ «Gulositas vilis et negligentis hominis putredo est», SAN BERNARDO, Lettere, CDLVI, Patrologia Latina CLXXXII, 649A.

${ }^{5}$ JOHN LEMPRIÈRE, Classical dictionary of proper names, London, Braken 1994, under «Cerberus».
} 
23) he has snakes «bristling on his necks», Virgil's Cerberus still has a sweet tooth. The Sybil feeds him a cake, honeyed and drugged; he eats it and falls asleep letting Aeneas pass. Dante makes him more horrific and grotesque by giving him some human features: red eyes, a greasy and black beard, a large belly, and clawed hands. These are tools with which Cerberus scratches the spirits, flays and tears them to bits: line 18 is a prodigious concentration of sound, rhythm and meaning: "Graffia li spiriti, scuoia e disquatra».The gluttons have become dead meat, and Cerberus a grotesque butcher.

The next terzina (19-21) responds to line 14 by focusing on the wretched spirits: under the rain, tormented by the hideous dog, they howl like dogs themselves, turning their bodies as they try to protect one side by exposing the other. Cerberus, noticing the two intruders, opens his three mouths wide and shows them his fangs. He looks like a great worm, incapable of keeping any part of his body still. Virgil scoops up some dirt with his hands and throws it into Cerberus's ravenous gullets, and the infernal dog devours it instantly, almost as if some other animal might want to steal it from him. Dante's simile, the only one in this short canto, offers a marvelously realistic description of a greedy dog (28-33).

At this point the watching ends and action begins, albeit in a most curious fashion. Dante and Virgil start walking, but, exceptionally, they do so «su per l'ombre», that is, over the shades that are beaten down to the ground by the rain. It is the first and only time that the two visitors walk over the shades in hell. ${ }^{6}$ This is puzzling. "We were passing over the shadows», Dante writes, but what can this actually mean? To ensure that we understand, he explains that he and Virgil actually placed their feet over the emptiness of the shades, which seemed real bodies («ponavam le piante / sovra lor vanità che par persona», 35-36). Dante may well have done so, though how remains a mystery; but surely Virgil could not do it, for Virgil is himself a «vanità» without real feet. Be this as it may, if they walk over the shades, how can they remain unaffected by the «piova etterna, maladetta, fredda e greve»? Dante does not say. He has time to specify that he and Virgil walked over the shades, but says nothing about them walking under the filthy mess. ${ }^{7}$

\footnotetext{
${ }^{6}$ All the hypocrites of the sixth bolgia, and presumably Dante and Virgil as well, thread upon the crucified Caiaphas, who suggested to the Pharisees that it would be better for Jesus to die than for the Jewish nation to be shattered (Inf. 23. 118-23).

${ }^{7}$ A point clearly made by ROBERT HOLLANDER in his footnote to this passage in Inferno, translation by Robert and Jean Hollander, notes by R. Hollander, New York, Anchor Books 2002, canto 6. 34-36, p. 123. In the case of the sodomites, with whom, as we will see, the gluttons seem to have much in common, we
} 
This is the first time that Dante and Virgil come into physical contact with the shades. It would then seem a perfect spot for Dante to satisfy a basic curiosity that the reader might have: what is it exactly that Dante sees, and comes into contact with, in his journey to the world of the dead?

Christians believe that, when people die, their bodies are buried on earth whilst their souls go to whichever destination their merits have earned them. But if the souls of the dead have no bodies, how can they suffer physical pains in hell and purgatory? The answer to this question will not come until we reach Purgatorio 25. ${ }^{8}$ Here, having seen the emaciated, skeleton-like figures of the penitent gluttons, Dante is puzzled: how is it possible - he asks Virgil - to become lean in the world of the dead, where there is no need for nourishment (Purg. 25. 20-21)? It may not be by pure chance that this question, which emerges on the circle of the gluttons in hell, finds a response (provided by Statius) on the terrace of the gluttons in purgatory. But if Dante had no intention of explaining the nature of the shades this early in the Inferno, why did he make a point of telling us specifically that he and Virgil walked over the gluttons?

We will return to this issue later. Now however, we must note that something else seems to preoccupy the poet. His description of the gluttons is extremely sparing: they were lying - he writes - all of them on the ground, and we walked over them. Those who have seen Peter Greenaway's film of Dante's Inferno will remember that the gluttons appear as a mass of fat and naked bodies lying thick on the ground under a steamy and filthy rain. However, Dante does not say a word about the bodies of the gluttons. He focuses immediately on one of the shades who suddenly sits up as he sees (or more likely hears) the two visitors pass before him.

Here starts the central episode of the canto. It takes its name from the name of its protagonist Ciacco, and it can be subdivided into three segments. In the first (ll. 34-57), Ciacco identifies himself as a citizen of Florence: "Your city, he says, which is so full of envy that already the sack runs over, held me within it» (49-50); he also openly declares himself, as all the shades around him, guilty of the damning sin of gluttony. "You citizens - he says called me Ciacco», which, if it is a nickname, means 'hog' (nomina sunt

are explicitly told that Dante and Virgil walk over the «margini» (stony banks or borders) in order to avoid the fireflakes that fall over the sinners (Inf. 14.141-42).

${ }^{8}$ A provisional answer, that does not explain anything, is given by Virgil in Purg. 3. 28-33. 
consequentia rerum); whatever it may mean, rhyming as it does with «sacco» and «fiacco», it doesn't sound too flattering. ${ }^{9}$

In the second segment (ll. 58-75), having heard that Ciacco is a Florentine, Dante asks him three precise questions regarding the future of Florence, and Ciacco prophesies the victory of the White Guelphs over the Black after a long struggle, and then the defeat of the White at the hand of the Black, thanks to the force of one who is now, in the year 1300, manoeuvring (Pope Boniface VIII): it should be noted that it was as a result of the Blacks' takeover that Dante was exiled at the end of 1301; Ciacco concludes mysteriously stating that in the whole city there are only two just men, ${ }^{10}$ but no one listens to them; pride, envy and avarice are the three sparks that have set the Florentine hearts on fire:

Giusti son due, e non vi sono intesi;

superbia, invidia e avarizia sono

le tre faville ch'anno i cuori accesi. (73-75)

Finally, in the third segment (76-93), Dante inquires about the whereabouts of some especially worthy Florentines - men who, when they were alive, used their minds to doing good - and Ciacco replies that they are farther down, among the blackest souls of hell. Which is bad news, of course, for if apparently worthy citizens are deeper down in hell, where will the bad ones be?

Having completed his reply, Ciacco asks Dante to remind people of him when he returns to the sweet world; then he falls back in the mud like all the other «blind» souls:

Li diritti occhi torse allora in biechi;

guardommi un poco e poi chinò la testa:

cadde con essa a par de li altri ciechi.

At which Virgil comments: «Più non si desta / di qua dal suon de l'angelica tromba» (He wakes no more till the sounding of the angel's trumpet, 91-95).

In the following last twenty lines of this very short canto Virgil explains two important details concerning the condition of the souls after the Last Judgment: first, Ciacco’s soul, as the souls of all departed, will be reunited to Ciacco’s body («ripiglierà sua carne e sua figura») on the day of

\footnotetext{
${ }^{9}$ See John A. ScotT, Perché Dante?, Firenze, Aracne 2010, p. 461, nota 60. Perché Dante?is the Italian translation by Stefania De Stefanis Ciccone, thoroughly updated and revised, of JoHN A. ScOTT, Understanding Dante, Notre Dame Indiana, University of Notre Dame Press 2004.

${ }^{10}$ See below for a different interpretation (and translation) of this line.
} 
the Last Judgment, when he will hear the sentence that will apply to him for eternity (95-99); and second, once body and soul will be reunited, the sufferings of hell, as the joys of heaven, will reach their perfect and definitive intensity (103-111).

Between these two explanations, one terzina (100-02) describes Dante and Virgil as they walk with slow steps through the foul mixture of the shades and the rain, touching a little on the life to come:

Sì trapassammo per sozza mistura

de l'ombre e de la pioggia, a passi lenti, toccando un poco la vita futura.

There is something odd about this: how can they walk through this foul, stinking environment «a passi lenti», without being touched by the filthy mixture, while conversing leisurely about the future life? This terzina echoes and largely repeats one at the beginning of the episode, where Dante states that he and Virgil walked over the shades (34-36):

Noi passavam su per l'ombre che adona

la greve pioggia, e ponavam le piante sopra lor vanità che par persona.

The imperfect "passavam», describing a continuous action in the past, has now become the preterite "trapassammo», which signals the completion of the same action. But it is hardly necessary, except in so far as it provides a narrative springboard for the introduction of a new topic: future life.

In the canto's concluding four lines Dante says that they walked round the curving road of that circle with much more talk than he now reports, and they came to the beginning of the descent where they found Plutus, the great enemy, guardian of the fourth circle. Thus the canto is framed at the beginning by a reference to the preceding circle and at the end by a reference to the next.

3. Though apparently simple, this canto has puzzled Dante's readers for centuries. Apart from the question of Ciacco's identity, which has never been historically established, there are a number of other substantial issues that are still controversial.

First, there is the issue of the contrapasso. What is the connection between sin and punishment in this circle? In purgatory, the gluttons are subjected to the sight of mouth-watering food and drink that they are unable 
to reach, and this penance seems to make perfect homeopathic sense: eventually, they will cease craving for what they don't need, and they will be cured. But what is the link between gluttony and the filthy rain the gluttons have to suffer in hell?

Second, there is the issue of Dante's walking over the shades (34-36): why does he do it, and why does he tell us about it while saying so little about everything else? More importantly, are the shades spirits or bodies? Raised at the beginning of the canto by Dante's reference to his walking over them, this question is clearly reinforced, at the canto's end, by the reference to the time when all souls will be reunited with their bodies; so we assume that the shades are spirits, but then how can bodiless spirits be trodden upon? How can they be tormented by rain, snow and hail?

Third, the traditional treatment of gluttony places it as the first step towards lust and other sins of incontinence. Dante does not seem to make this connection. ${ }^{11}$ Instead, he associates gluttony with Florentine politics.

Fourth and most important question, what is the connection, if any, between gluttony and Florentine political rivalry? ${ }^{12}$ Ciacco is not in hell as a sociopath or a political schemer, but as someone who did not control his craving for food and drink. Why then does he place Florence, rather than food and drink, at the center of his personal obsession? What authority has he got to speak about politics? How can he, who devoted his life to eating and drinking, know that there are only two just men left in Florence? And who are they? And finally how can he specify with such sharp and insightful moral clarity that the cause of the present strife, the sparks that set the Florentine hearts on fire, are pride, envy, and avarice? The readers of this canto $^{13}$ agree that its main focus is Florence, and emphasize its connections with Inferno 10 and 15, the cantos of Farinata and Brunetto, two other eminent citizens of Florence. Equally obvious and acknowledged are the formal and thematic connections between Inferno 6, Purgatorio 6, and

\footnotetext{
${ }^{11}$ But see, particularly with reference to Dante's treatment of gluttony in Purgatorio, GABRIELE MuRESU, Forese e la gola (Purg. XXIII), «L’Alighieri», XXIX n.s., 2007, pp. 5-29, especially pp. 16-21.

${ }^{12}$ See HOLLANDER, note to Inf. 6. 49-51 with reference to gluttony and political rivalry: «Many commentators try to find reasons to explain Dante's having related the two, but none has found a genuinely convincing link». ANDRÉ PÉZARD (Le cant vi de l'Enfer: Ciacco et Florence, «Bulletin de la Société d'Etudes Dantesques du Centre Universitaire Mediterranéen», XII, 1963, pp. 7-34) si domanda «comment et pourquoi, dans la structure dramatique du chant VI, le poète pourra se permettre d'associer, ou plutot de substituer sommairement, au péché de "gueule, le péché de guerre civile», p. 8.

${ }^{13}$ See in particular PÉZARD, cited above; MARIA PICCHIO SimonelLi, Florence, Ciacco and Gluttony, in Lectura Dantis: Inferno, ed. by Allen Mandelbaum, Anthony Oldcorn and Charles Ross, Berkeley, University of California Press 1998, pp. 84-100; ZYGMUNT G. BARANSKI, Inferno VI, 73: A Controversy Re-Examined, «Italian Studies», XXXVI, 1981, pp. 1-26, revised and published in Italian in ID., Sole nuovo, luce nuova. Saggi sul rinnovamento culturale in Dante, Torino, Scriptorium, 1996, pp. 183-219.
} 
Paradiso 6, for the three cantos deal respectively with Florence, Italy and the Empire. But there are links also with Inferno 16, Purgatorio 16 and the cantos of Cacciaguida, Paradiso 15-16. Altogether, this group of cantos forms a major thematic network in the Comedy. ${ }^{14}$ Which again proves how fundamental for Dante's political universe is the matter treated in Inferno 6. But why then raise it in connection with gluttony and entrust it to the voice of an obscure Florentine? For there seems to be a disproportion, in terms of personality, between Ciacco and such exceptional spokesmen as Farinata, Brunetto and the three noble Florentines, not to mention Dante's ancestor Cacciaguida. Whichever way we choose to look at it, Inferno 6's peculiar mix requires an explanation that is not structural.

Finally, the canto raises these questions, but does not even begin to answer them; yet with its 115 lines it is, with canto 11, the shortest of Inferno. At the end of it, Dante says that, as he walked with Virgil, they talked about many things which he does not report on. Something similar happens at the end of Inferno 4, but that is a canto of 151 lines; it happens again at the end of canto 33 of Purgatorio, which however is a 145 line canto. We must then assume that, in the case of Inferno 6, Dante deliberately chooses to keep it short, but why?

4. The limits of this contribution allow me to consider only some of these issues, and I want to begin with the «contrapasso», for oftentimes a correct and full understanding of the «contrapasso» helps to resolve other problems as well. A compelling answer was given, forty years ago, by Robert Dombroski: in a nutshell, the stuff that falls from above upon the gluttons is a kind of anti-manna. ${ }^{15}$ The story of the manna in Exodus 16. 1-4 is one of the most widely known of the Bible. Six weeks after their exit from Egypt, the people of Israel find themselves in the desert without food or drink. They bitterly complain to Moses wishing they stayed in Egypt, where they had plenty of meat and bread. Then God starts raining manna upon them so that they would not despair of His power. Thus the manna Dombroski writes - «becomes the means of satisfying the needs of the body in order that the spirit may better endure in its battle» against the servitude of sin. On the contrary, the gluttons have perverted the function and place of

\footnotetext{
${ }^{14}$ See, among others, SIMONELLI, pp. 84-87.

${ }^{15}$ ROBERT S. DOMBROSKI was a distinguished American scholar of modern Italy, author of some major works on Gadda. I had the privilege of being close to him in the last years of his life. His short The Grain of Hell: A Note on Retribution in Inferno VI, published in «Dante Studies», LXXXVIII, 1970, pp. 103-108, is his only contribution to Dante studies.
} 
food in the order of things; food has become for them an end in itself, and as a consequence, what they receive is an anti-manna, the heavy and cold food of hell.

I think that Dombroski's intuition is correct. However, he did not follow up some interesting details of the story of the manna as told not in Exodus, but in the book of Numbers. Here the people of Israel, overcome by greed, start weeping and ask: "Who shall give us flesh to eat?» ${ }^{16}$ They remember the fish, cucumbers, melons, leeks, onions and garlic they freely ate in Egypt, and treat the manna with contempt. God sends them an enormous quantity of quails, and they gather and eat them. "And while the flesh was yet between their teeth, ere it was chewed, the wrath of the Lord was kindled against the people; and the Lord smote the people with a very great plague» (Num. 11.33-34). So here, in all evidence, are our gluttons, who, not content with God's food, crave after meat and other dainties, and are therefore punished.

But there is more. A little later, instructed by God, Moses sends a group of explorers, one for each tribe, to inspect the land of Canaan that God wanted to give the people of Israel. Upon their return, some of the explorers say that it is a land where milk and honey flow, and exhort the people to go and take it over (Num. 13.27-30); others, however, report that it is an evil land that devours its inhabitants (Num. 13.32). Frightened, the people refuse to move to Canaan and start planning instead a return to Egypt (Num. 14.34). Two of the explorers, Caleb and Joshua, try to persuade them to do God's bidding, but the Israelites refuse and threaten to stone them to death. God gets very angry and tells Moses to tell his people that he will punish them: they will all be killed and consumed in that desert, except two of them, Caleb and Joshua (14.26-38); only they will enter the promised land.

Commentators since Boccaccio have been looking for the two just men of Ciacco's prophecy. ${ }^{17}$ I suggest that they are here, or at least that here

\footnotetext{
${ }^{16}$ Num. 11.4. The English text quoted here and throughout is that of the King James Bible, unless otherwise specified.

${ }^{17}$ PÉZARD (p. 26), and many after him, points to Matthew 18.19-20 as a probable source for Dante's «due giusti»; others (for example, SAPEGNO , PASQUINI-QUAGLIO and CHIAVACCI LEONARDI in their commentaries on the Commedia) suggest instead the «tres viri iusti» of Ezechiel 14.13-14. As for the number two of «due giusti», it is usually explained as meaning very few. FRANCESCO MAZZONI, Tematiche politiche fra Guittone e Dante, in Guittone d'Arezzo nel settimo centenario della morte. Atti del Convegno Internazionale di Arezzo (22-24 Aprile 1994), a cura di Michelangelo Picone, Firenze, Cesati 1995, pp. 351-383, especially pp. 379-383, suggests that Dante does not refer to two men, but to two kinds of justice, natural and legal. BARANSKI demolishes both PÉZARD's and MAZZONI's arguments (Sole nuovo, pp.191196), but then he suggests the story of Sodoma as a possible source (Gen. 18.23-24) arguing that we should be satisfied with the allusiveness of Dante's «giusti son due», while at the same time recognizing that one of them must be Dante (206-210). Claudia Di Fonzo, Giusti son due e non vi sono intesi,
} 
is where Dante finds them. As Ciacco states of Florence, so does the Bible state of the people of Israel: gluttony is only a manifestation of their moral and civil corruption. In Florence just as among the people of Israel, only two citizens are not corrupt, only two do not crave after the meat of Egypt. The difference is that, contrary to the biblical example, Ciacco does not give their names.

The soundness of this source is confirmed by the way in which it is treated by many medieval exegetes starting from Saint Ambrose. In his De Helia et Ieiunio, Saint Ambrose argues that food is the bait with which the devil ensnares us. He describes, in amusing terms still relevant today, what goes into the preparation of a banquet - the frantic search for special foods in the market, the anxiety of the host over the expenses, the mad chaos and noise in the kitchen, the cook's distress, the curses and protestations of the servants... "You would think it not a kitchen but a slaughter house; that a battle was being fought, not a dinner prepared; so does everything swim in blood [...]. One is a slave to an evil mistress, the appetite (gulae), that is always seeking and is never satisfied. For what is more insatiable than the stomach?» $^{18}$

Ambrose devotes a great deal of attention to drunkenness and its devastating effects. He considers wine a poison for both mind and body; through the abuse of wine, man runs the risk of transforming his body into mud, he writes. ${ }^{19}$

Drunkenness is the kindling wood of passion, drunkenness is the incentive of madness, drunkenness is the poison of folly. This vice changes the senses and forms of men, through this vice from men they become neighing horses; since indeed being warm with the natural heat of the body and inflamed beyond the measure of nature by the heat of wine, they cannot restrain themselves and are excited to bestial passions [...]. They lose their voice, they change color, their eyes burn with passion, they pant with open mouth, they snort with distended nostrils, they are enkindled into rage, they go out of their senses. From this comes dangerous delirium, from this comes the heavy affliction of gall stones, from this comes fatal indigestion, from this comes frequent vomiting [...] I speak falsely if the Lord has not said the same through Jeremias in these words: Drink ye, and be drunken, and vomit: and ye will fall and will rise no more. ${ }^{20}$

«Forum italicum», XLIV, 2010, pp. 5-36, has recently argued extensively for Mazzoni’s proposal without however making it more persuasive.

${ }^{18}$ «Malae dominae servitur gulae, quae semper expetit, numquam expletur. Quid enim insatiabilius ventre?»: S. AmBrosiI, De Helia et Ieiunio. A Commentary, with an Introduction and Translation, by Sister Mary Joseph Aloysius Buck, Washington DC, The Catholic University of America 1929, VIII, 25-26 (PL XIV, 706).

${ }^{19}$ De Helia, XIV, 51: «periclitatur homo lutum esse de corpore» (PL XIV, 715).

${ }^{20}$ De Helia, XVI, 59 (PL XIV, 718). The citation is from Jeremiah 25.27. 
Ambrose's last quotation cannot fail to raise our interest. Jeremiah's original text, as quoted by Ambrose, is «Bibite et inebriamini, et vomite, et cadetis, et non surgetis». This is an extraordinary coincidence. Jeremiah's sarcastic address to the gluttons resonates almost literally in Virgil's comment on Ciacco's falling back to the ground in the filth and vomit of the third circle: «Più non si desta» (line 94). ${ }^{21}$ Thus, through Virgil's mouth, Dante verifies Jeremiah's warning and prediction.

This is not all. Even more upsetting for Saint Ambrose is the effect that wine has on women.

These in the public squares perform, before the gaze of debauched youths, dances shameless even to men, tossing their hair, trailing their tunics, with torn garments, with naked arms, clapping their hands, leaping with their feet, uttering loud cries, inciting the passions of the youths towards themselves by their histrionic movements, impudent eyes, and disgraceful wantonness.

Ambrose concludes warning his readers that:

those tribes of the fathers, while they drank water from the rock, and while they ate manna, conquered the strongest nations [...] But when they began to desire flesh and were turned by their desires to Egypt, out of so many thousands of men not more than two deserved to enter the land of promise. ${ }^{22}$

In this passage again, the two just Israelites of the book of Numbers appear in close association with manna and 'anti-manna', and, significantly, Ambrose does not give their names, for his focus, like Dante's, is not on the few who will be saved, but on the many who will be punished. Ambrose treats gluttony not just as a private vice, but as a public evil, a symptom of a religious, civil, social, and even military breakdown that can be fatal for an entire nation or city. Now Ciacco's Florentines are just like the people of Israel. They spurn the spiritual manna, craving instead after meat and wealth. This, I suggest, is Dante's concern and ultimately what the canto is about: the civil, moral and political disintegration of Florence, of which the excesses of gluttony are but a sign.

Indeed, if we now go back and re-consider the exchange between Dante and Ciacco, we cannot fail to notice that, from its very beginning, the focus of this exchange is not so much gluttony as the repugnant rottenness of

\footnotetext{
${ }^{21}$ Quella dell'ubriaco che perde i sensi e cade a terra è un'immagine ricorrente in queste pagine ambrosiane, vedi per es. § 57: «aureum est hoc vas, poculum est: in eo poculo venenum mortis, venenum libidinis, venenum ebrietatis est. Hoc qui biberit, commovetur et cadit» (PL XIV, 717).

${ }^{22}$ De Helia, XVIII, 66 and 68 (PL XIV, 720-721); my italics.
} 
Florence. The syntax of Ciacco's first sentence clearly betrays this displacement of focus, for it is not the principal clause («La tua città [...] seco mi tenne in la vita serena»), but the relative clause («ch’è piena d'invidia sì che già trabocca il sacco») that conveys the important message. The metaphor describes Florence to a sack of envy so full that it already spills over. The verb «trabocca », a verb that Dante uses here for the first and only time in the poem, is very suggestive. The sack has a «bocca», a mouth, through which envy overflows. In other words Florence is a body so stuffed with envy that it vomits it out. The following two terzine re-inforce this reading of the first: the second begins «Voi cittadini», and refers immediately to Ciacco's «dannosa colpa de la gola» (as a true Florentine, Ciacco overfills the sack of his body); the third terzina extends Ciacco's vice to all the others who dwell on the same circle. The circle itself then, like Florence, overflows with spirits guilty of gluttony. At this point however, the issue is no longer gluttony but the corrupted city and its citizens. Not surprisingly then Dante does not ask Ciacco about overconsumption of food and drink, but rather about the devastating conflict that rages among the citizens of the divided city.

5. There are reasons to believe that Dante knew not only the books of Numbers and Jeremiah, but also the works of Saint Ambrose, where these two books are so often quoted. ${ }^{23}$ But there is another biblical text, a poetic and prophetic text, where the issues raised by Inferno 6 seem to be displayed in an exemplary manner, another text which we may assume Dante was familiar with. André Pézard quoted and discussed it extensively in his insightful reading of Inferno $6,{ }^{24}$ without however raising the attention that he deserved. I'm referring to the book of the prophet Isaiah, a book that Dante quotes a few times in the Comedy and elsewhere in his work. ${ }^{25}$ Before looking at this text, it should be mentioned that some aspects of Isaiah's biography and writings are likely to have struck Dante as close to his own experience. Like Dante, Isaiah, who lived in the 8th century BCE, was a political man, a poet and unheeded prophet who tirelessly denounced the moral degradation that economic prosperity brought to Israel. In the Christian tradition he is treated as a saint and a prophet of the coming of Christ. There are various passages in his book that resonate with Inferno 6:

\footnotetext{
${ }^{23}$ See Ugolino Nicolini, «Ambrogio, santo», Enciclopedia Dantesca I, p. 201.

${ }^{24}$ PÉZARD, especially pp. 9-10. In addition to the article cited above see also A. PÉZARD, «Ciacco», ED I, pp. 982-986.

${ }^{25}$ See ANGElo PenNa, «Isaia», ED III, pp. 520-521.
} 
most of them are about gluttony, or, more precisely, drunkenness: indeed, Isaiah is often quoted in sermons against gluttony. ${ }^{26}$ There is a collection of sermons, probably by Hugh of Saint Victor, in which gluttony is condemned almost exclusively on the basis of quotations from Isaiah. ${ }^{27}$ Here are some passages:

Isaiah 5. 11: «Vae qui consurgitis mane / Ad ebrietatem sectandam, / Et potandum usque ad vesperam, / Ut vino aestuetis! » (Woe unto them that rise up early in the morning, that they may follow strong drink; that continue till night, till wine inflame them!)

Isaiah 5. 22: «Vae qui potentes estis ad bibendum vinum, / Et viri fortes ad miscendam ebrietatem» (Woe unto them that are mighty to drink wine, and men of strength to mingle strong drink!)

Isaiah 55. 10-11: «Et quomodo descendit imber et nix De caelo, et illuc ultra non revertitur» (For as the rain cometh down, and the snow from heaven, and returneth not thither...)

Isaiah 56. 11 compares the drunkards to «canes impudentissimi, Nescierunt saturitatem» (most shameless dogs, whose eating never satisfies them), a passage often quoted in the Middle Ages as an authority against gluttony. Dante himself compares the gluttons to dogs.

All these passages resonate with Inferno 6. However, the most significant segment is Isaiah 28, which consists of an oracle addressed first (1-4) to the Kingdom of Israel and in particular the city of Samaria, and then to the Kingdom of Judah and the city of Jerusalem. In the first verse Samaria is presented as a proud city, and its inhabitants as drunkards («ebriis Ephraim»), laid low by wine. The second verse speaks of a powerful and strong messenger from God who, «Like a hailstorm and a destructive wind, / Like a driving rain and a flooding downpour», ${ }^{28}$ will throw the city and its inhabitants to the ground. Further down, Isaiah presents the people as totally stupefied by drunkenness, their dining tables covered in vomit and filth («vomitu sordiumque»): there is not a spot that is clean (28. 7-8). ${ }^{29}$ A little

\footnotetext{
${ }^{26}$ Saint Ambrose bases the third part of his De Helia (§§ 69-85) on Isaiah 23.

${ }^{27}$ Sermones centum, XXXVIII: De Babylone, id est saeculari conversatione per septem crimina, fugienda, PL CLXXVII, 997A-B. The sermon discusses the seven capital sins in the exact order in which they appear in Dante's Purgatorio. Gluttony is found on the sixth platea (a long and wide avenue) and it includes both edacitas (voracity) and ebrietas (drunkenness).

${ }^{28}$ Quoted by PÉZARD, pp. 11-13; italics mine.

${ }^{29}$ This is where PÉZARD suggests that Dante found inspiration for the «contrapasso». Gluttony is often associated with vomiting probably on the authority of Isaiah 28.8: see THOMAS AQUINAS, Summa
} 
further, the Lord speaks through Isaiah saying that «the hail shall sweep away the refuge of lies, and the waters shall overflow the hiding place» («Et subverted grando spem mendacii, et protectionem aquae inundabunt», 28.17). Finally, the third verse prophesies that the proud drunkards of Ephraim will be trodden under feet: «Pedibus conculcabitur / Corona superbiae ebriorum Ephpraim». ${ }^{30}$

This is remarkable. Here we have, one after the other, the three major elements that appear together in Inferno 6: one, the gluttons as drunkards; two, the drunkards thrown to the ground by hail and driving rain; and three, God's messenger, trampling them under his feet. If this is indeed the biblical intertext that inspires Inferno 6, I suggest that, even at this very early stage of the poem, Dante is writing as the modern Isaiah, the unheeded prophet of Florence's doom.

6. But there is more in this passage that is likely to have inspired the poet of the Comedy. We have seen how, having replied to Dante, Ciacco falls back onto the filthy ground «a par de li altri ciechi». Why «ciechi»? The common explanation is that it is a metaphorical blindness, quite understandable in the «blind world» ${ }^{31}$, the «blind prison» ${ }^{32}$ of Hell, and more so in the third circle where the damned wallow in mud and repugnant liquids. However, far from being innocent, this sobriquet may allude to the Florentines, who were proverbially known to be «orbi», ${ }^{33}$ as Brunetto Latini will declare in Inf. 15.67: "Vecchia fama nel mondo li chiama orbi».

Interestingly, this is not the only connection beween Ciacco's and Brunetto's speeches. In the following line (Inf. 15.68), quoting in reverse order Ciacco's «superbia, invidia e avarizia sono / le tre faville c' hanno i cuori accesi» (74-75), Brunetto defines the people of Florence in these terms: «gent'è avara, invidiosa e superba». Also his following two terzine resonate with echos of Inferno 6:

La tua fortuna tanto onor ti serba, che l'una parte e l'altra avranno fame di te; ma lungi fia dal becco l'erba.

Theologiae, 2a 2ae, 148. 6: «immunditia, quae maxime consequitur gulam, videtur ad vomitum pertinere»; Aquinas cites Isaiah and continues by stating that vomiting seems to be a punishment for the sin of gluttony, rather than a sin in and of itself.

${ }^{30}$ See PÉZARD, p. 20. Same image of the proud being trodden upon in Isaiah 26. 6.

${ }^{31}$ Inf. 4.13 and 27.25

${ }^{32}$ Inf . 10.58-59 and Purg. 22.103

33 «noi Fiorentini detti orbi e inn-antico volgare e proverbio per li nostri difetti e discordie»: GIOVANNI

VILlAnI, Nuova cronica, XIII, 17, ed. by Giovanni Porta, Parma, Guanda 1991. 
Faccian le bestie fiesolane strame

Di lor medesme, e non tocchin la pianta,

s'alcuna surge ancora in lor letame,

in cui riviva la sementa santa (70-76)

The reference to the hunger of the Florentine political factions, that is, the Black and White Guelphs, takes us straight back to the gluttons, even if the hunger Brunetto refers to, just as the blindness above, is only metaphorical. The Florentine factions are defined by Brunetto as famished beasts, eager to devour Dante Alighieri. The beasts are goats («becco») and Dante the grass («erba») they crave for, but the grass will be out of their reach. They are then contemptuously advised to make forage («strame ») of themselves, rather than touch the plant («la pianta ») in which the sacred seed («la sementa») of the Roman race still lives on - provided of course that any plant still grows in their dung («letame»). The analogies with the gluttons are impressive. Not unlike the gluttons who live like dogs in their vomit and filth, the Florentines are grimy beasts who eat each other and live on their own excrement. Dante instead is «erba, pianta, sementa »-all healthy, vegetal metaphors of natural, growing, living things, in striking contrast with the decaying state of the Florentine animals.

This contrast already appears at the beginning of Brunetto's speech where he declares that, because of Dante's good deeds, the Florentines will turn against him. But that makes sense, he adds, «ché tra li lazzi sorbi / si disconvien fruttare al dolce fico» (Inf. 15.65-66), i. e., in Longfellow's translation, «for among crabbed sorbs it ill befits the sweet fig to bear fruit». This time the contrast is not between healthy and decaying things, but between the edible and the inedible fruit. Dante is the sweet fig that cannot fructify among the harsh and bitter sorbs, but he is obviously also the sweet fig that the Florentines crave to devour. Thus the fig becomes another significant link that bridges the distance between canto 15 and canto 6 .

The metaphor of the fig and the sorbs is said to belong to a «modo proverbiale di parlare, forse proprio del Brunetto storico». ${ }^{34}$ This may well be so; however, in the passage that we have already highlighted (28.1-4) Isaiah has a fig, which everyone wants to eat as soon as they see it. Here is the Latin text as it appears in Saint Jerome's commentary on Isaiah, the only text in which the fig appears:

\footnotetext{
${ }^{34}$ See ChIAVACCi LeONARDi’s note to Inf. 15.65-66. But John HARRIS, Three Dante Notes, «Lectura Dantis (Virginiana)», II, 1988, pp. ?-?, writes: «There is an almost coquettishly sexual quality to this image of the "sweet fig" amidst the "bitter sorbs"».
} 
Et erit flos qui decidit de spe gloriae in summitate montis excelsi, sicut praematura ficus, quam qui viderit, antequam sumat manu, cupiet eam devorare.

(And the flower that falls from the hoped for glory at the top of the high mountain will be like the early fig which, whoever sees it, will want to devour it even before holding it in his hand. $)^{35}$

Here we have the fig of Brunetto combined with the gluttony of Ciacco, and in the background the gluttons of Florence/Ephraim thrown to the ground by hail and rain, and trampled underfoot by God's messenger: all Isaiah images. Canto 15 is a continuation and development of canto $6,{ }^{36}$ and Dante's Brunetto speaks with the same voice as Dante's Ciacco: the voice of the prophet Isaiah.

What surprises in his rich and suggestive intertextual practices is that, in excerpting and redeploying his texts, Dante does not seem to care much about what I would call the homogeneity and suitability of the contexts. The mouth of Ciacco, that used to overflow with food and drink, now speaks the words of Numbers, Jeremiah and Isaiah, indeed the words of God. Both Ciacco and Brunetto are mortal sinners, condemned to suffer for ever and ever in hell, and the conditions in which Dante 'finds' them are disgusting in one case and undignified in the other, to say the least. Yet, both are made to speak with the authority of prophets. Shockingly inappropriate for us, but obviously not for Dante.

\footnotetext{
${ }^{35}$ For the text see $P L$ XXIV, 315B. This is very likely to be the text of the Bible that Dante was familiar with: see JoHn A. SCOTT, Understanding Dante, p. 299. The translation is mine. The text of the Vulgate drops the comparison with the fig: «Et erit flos decidens gloriae exsultationis eius, Qui est super verticem vallis pinguium, Quasi temporaneum ante maturitatem autumni, Quod, cum aspexerit videns, Statim ut manu tenuerit, devorabit illud».

${ }^{36}$ See BARANSKI, Sole nuovo, pp. 211-15.
} 
